\title{
AN INTRODUCTION TO NORTH AUCKLAND FARMING
}

\author{
M. L. CAMERon
}

Fields Superintendent, Department of Agriculture,

The soils, climate, history and the production trends of the North Auckland peninsula, up to 1952, are fully described by Taylor and Sutherland (1953). However, a review of progress since that time is justified if it can point the way to the future.

Even from a cursory examination of the history of the North Auckland peninsula, one cannot fail to conclude that it was the timber, the kauri gum and the flax of Northland which laid the foundations of Auckland, just as it is an inescapable conclusion that this extractive, colonial phase ultimately impoverished and depressed the north. The recovery has been slow and hard won. The combination of capital starvation and seemingly insurmountable technical problems sapped the initiative and the confidence of those who staked their future in the north - they could neither progress nor get out. As the answers to the problems of the soil gradually emerged, the few who still had confidence had little hope of applying the new knowledge. Those who held the purse strings did not share their confidence.

In the early fifties, New Zealand experienced a few years of boom conditions. Re-investment in farming was probably at a higher level than at any other time this century. For three reasons, the north was unable to take advantage of the short, golden period before taxes and costs caught up. First, there were too many basic problems of soil fertility to be solved - the answers were close at hand but not clearly demonstrated. Secondly, farming was still at sustenance level and even with high prices and low costs there was not enough finance left over to begin the process of revitalizing the economy. Thirdly, and the most important factor, the people had no confidence. The disappointments of the past had led to the inevitable conclusion that the north was different and what worked in the rest of New Zealand just would not work there. It looked as if the region was fated to fall further behind, but the solution came. 
In 1953, J. Bruce Brown detailed a massive land development programme planned for Northland. At that time, just under 25,000 acres had been sown in grass. Since then, 86,201 acres have been developed, representing a capital investment by the Crown of $\$ 30$ million* in grass, stock, houses, roads and all the contingencies that the plough brings in its train. The Marginal Lands Scheme has invested another \$7 million" while State Advances lending has injected a further $\$ 18$ million.* This investment in the north, totalling approximately $\$ 55$ million has, more than anything else, rebuilt the economy. Not only has it created new farms from wasteland, but it has brought new life to many of the towns and villages, improved roads and services, attracted young and vigorous people, and, most important of all, it has underwritten the confidence of those who farm there and those who can finance them. The confidence, enthusiasm and the vigour of the immigrant generation has spread to the indigenes resulting in a record of progress which, today, is probably unequalled -anywhere in New Zealand. The region is attracting young men and women who are willing to face the long hours, hard work and low living standards that are the price of entry into dairy farming today. The commonly-held beliefs that the north is different and unable to match the productive performance of more southern latitudes are being swept away as progressive and better-established farmers match the records of the developed regions with power in hand. With practical solutions to most of the soil fertility problems found, and pathways to the solution of utiiization problems well defined, the stage at last is set for the fuller exploitation of what is undoubtedly the north's greatest asset-its unique grassland climate. Whether this will be realized as soon as is physically possible will depend largely on the economic and social climate of the next decade.

The story of physical progress in the north differs little from other farming regions where soils, climate and contour dictate grassland and livestock enterprises. Starting from a lower baseline, the peninsula has made more rapid progress than many other areas, but it has been progress up to, rather than ahead of average New Zealand productivity. The north is still far from generating sufficient capital, within the region, to assure the minimum rate of expansion which its level of indebtedness dictates. It must have new capital. There is no turning back, nor even is

* Figures approximate only. 
there room for hesitation. The influx of capital must be continued at a high level if the region is to lift itself out of its state of underdevelopment and realize the pay-off from investment to date. Not only does it have to catch up on lost ground, but it must keep pace with the ever-rising productivity on which the survival of $\mathrm{New}$ Zealand farming depends. I believe the case to be clearcut - the north must have continued financial support from all sectors; it needs young, physically fit people; it needs people with adequate capital ; it can no longer afford to welcome the undercapitalized, inexperienced settler drawn to the north in the past by the myth of cheap land. Cheap, undeveloped land, little or no capital, short-term vendor mortgages and inexperience are the ingredients which breed rural slums. It is to be hoped the lessons of the past have been learnt well.

During the last decade and a half, quarter-of-a-million acres" have been won back into grass, an increase of $14 \%$ to nearly 3 million acres occupied. Of this increase, $34 \%$ has been Crown Land development. One can only guess at the remainder which offers an immediate development prospect, but it is probably in the vicinity of half-a-million acres, scattered throughout the region, often in small blocks or in existing holdings. The importance to the region of the development of all the land which is suitable for farming cannot be over-emphasized. It is the only hope of providing the revenue necessary to maintain and improve communications and services at a reasonable cost.

Without doubt, the most spectacular change has been the increase in fertilizer used. Since 1952, the tonnage has increased by $84 \%$ ( $1964-5)$. More acres are receiving more fertilizer. In 1951-4, 51\% of the grass received an average dressing of 3.3 cwt while in 1964-5 70\% received 3.7 cwt. Lime use, which had declined steadily since the termination of the Lime Transport Assistance Scheme, passed the peak level of the early fifties in 1964-5.

It is difficult to comment on the relationship between the use of fertilizer and stock carried since it is a period when part of the fertilizer used represents what is commonly termed "capital dressings" -high rates to overcome the initial deficiencies of low fertility soils. In the three-year period 1951-4, 2.2 ewe equivalents were supported by each 1 cwt of fertilizer. In 1964-5, this had fallen to 1.4 ewe equivalents. However, animal productivity had increased

\footnotetext{
, ${ }^{*}$ Unless otherwise stated, the statistics quoted include the nine counties north of Auckland, the land area described by Arnold and Scott (1953).
} 
remarkably over this period. It is impossible to obtain a measure of the rise in productivity of the sheep and cattle industry but if one assumes a gain similar to that achieved in the dairy industry, $28 \%$, the adjusted carrying capacity indicates that, in spite of the rise in productivity, fertilizer use is at least $22 \%$ less efficient. This is the price that must be paid for a rapid increase in production. The financially secure farmer has been encouraged to use his farm as his bank and has quickly realized that it is good- business to indulge in a luxury level of fertilizer use. The rapidly developing farm, too, has been encouraged to increase fertilizer use at a rate beyond its capacity to increase stock or provide for other contingencies. Varying seasons, lack of precise knowledge of the relationships between fertilizer inputs and stock outputs, and wide variations in the efliciency of farmers as converters of grass to animal products have been, and will continue to be important limits to efficiency. However, in a region where fertilizer costs at present represent From 25\% to 50\% of total cash expenses, improved efficiency in the use of fertilizer is synonymous with more efficient farming. This must be a goal of farming in the north in the next decade. It is not suggested that there should be a reduction in fertilizer use, but, rather, an all-out effort to cash in on an annual investment in lime and fertilizer of more than $\$ 8$ million. A high proportion of farms in the north are rapidly reaching the stage where an increase in stocking rate is a more productive investment than investment in further fertilizer.

In common with all the major dairying areas in $\mathrm{New}$ Zealand, the north has experienced a technical and structural revolution in the industry. Dairy cows in milk have increased by only $4.4 \%$, but there have been vast changes in organization and productivity. The number of herds of 10 cows and more in the Northland statistical region has fallen by $24 \%$ to 3,800 ; the average herd size has risen from 50 cows in 1950-5 to 73 in 1964-5, and per-cow production has risen $28 \%$ from $213 \mathrm{lb}$ to $272 \mathrm{lb}$ butterfat. Whereas per-cow production was $11 \%$ below national average, it is now only $6 \%$ lower, while average butterfat per farm in rising from 10,700 to $19,800 \mathrm{lb}$, although still substantially lower than national average, has increased at a faster rate. Of even more significance is the evidence that the north is on the threshold of a rapid increase in cow numbers as initial tuberculin testing is completed and the increased number of female stock retained come into production. The development of low-cost systems of "off-grass 
wintering" has advanced to the stage where it has become feasible to utilize a much higher proportion of the grass produced. While the cost of utilization may well be higher than in the freer draining soils of the North Island, the longer period of pasture growth and the higher ceiling of total grass production offset this disadvantage and indicate that potential per-acre production could well be higher than in any other region in N ew Zealand.

Processing too, has undergone structural change. In 1952-3, sixteen factories processed 67,400 tons butterfat ; in 1965-6, nine factories processed 87,000 tons. In wholemilk collection, by diversification of products and produce handling, $\mathrm{N}$ orthland has kept abreast of other areas and, in many spheres, leads the way.

The development of aerial topdressing has been one of the major factors influencing the rise in sheep and cattle numbers since 1952. Total sheep numbers now exceed twoand-a-half-million, an increase of $161 \%$ in 14 years. Breeding ewes represent nearly $70 \%$ of the total, and have increased by $189 \%$. Latest figures show that sheep numbers in Northland are increasing at three times the national rate.

Beef cattle numbers have not kept pace with the rise in sheep numbers, a reflection of their relative profitability, the changing market demand for beef and the greater proportion of improved hill pasture. Cattle numbers have risen at a steeper rate in the last two seasons as profit margins between beef and sheep have narrowed, but traditional beef production still suffers from the considerably higher investment cost of breeding stock relative to sheep.

In surveying the north of the sixties, I have tried to convey something of the changes, both physical and mental, that have taken place. Other pipers examine and evaluate the application of current technology in the real-life farm situation. There can be no doubt that it is a success story science has solved the critical technical problems, finance to do the job has been provided, the extension programme has shown the farmer how to do it and has convinced him that it is worth while, and, most important of all, the farmer is progressing in a spectacular way.

What of the immediate future? The region can now say, with confidence, that investment in farming can be highly profitable, The need for investment is just as clear. Every additional ton of milk powder and every additional prime lamb means more investment on the farm, in transport, processing and servicing. If the pay-off from the considerable new investment of recent years is to be realized, and if 
farmers are to catch up and win the race to economic independence, finance must be made available. The source is of little moment provided it is forthcoming. Investment must be serviced if it is to be used efficiently. Research will provide many of the answers but the greatest gain can come from matching investment with advisory resources to meet the need investment creates. I am confident there are no technical barriers, that the farmers have the ability and the will to do the job. If the resources are made available, the future of the north is bright indeed.

\section{REFERENCES}

Arnold, E. H.; Scott, R. H. 1953: Proc, 15th Conf. N.Z. Grassl. Ass., 39. Brown, J. B. 1953: Proc. 15th Conf. N.Z. Grassl. Ass.; 55.

Taylor, N. H.; Sutherland, C. S. 195.3: Proc. 15th Conf. N.Z. Grassl. Ass., 25.

\section{DisCUSSION}

Were the figures quoted up to 1964-5, and could stock numbers have increased since then?

Yes. Stock numbers have increased considerably over the last two seasons.

Would the largest remaining areas be in gorse, and therefore expensive fo develop?

No. Manuka and fern are the predominant scrub cover. Gorse is prominent close to roads and can give a misleading impression.

Where is the southern boundary of the area under discussion?

Unless otherwise stated, all the figures quoted refer to the nine counties north of Auckland as described by Arnold and Scott, 1953. This includes Rodney and Waitemata counties. In 1960, the statistical district of Northland, made up of the seven northern counties, was defined, and any figures that refer to this statistical area have been described in this way in the paper. 